\title{
Identification and genotyping of feline infectious peritonitis-associated single nucleotide polymorphisms in the feline interferon- $\gamma$ gene
}

\author{
Li-En Hsieh and Ling-Ling Chueh*
}

\begin{abstract}
Feline infectious peritonitis (FIP) is an immune-mediated, highly lethal disease caused by feline coronavirus (FCoV) infection. Currently, no protective vaccine or effective treatment for the disease is available. Studies have found that some cats survive the challenge of virulent FCoV isolates. Since cellular immunity is thought to be critical in preventing FIP and because diseased cats often show a significant decrease in interferon- $\gamma$ (IFN- $\gamma$ ) production, we investigated whether single nucleotide polymorphisms (SNP) in the feline IFN- $\gamma$ gene (fIFNG) are associated with the outcome of infection. A total of 82 asymptomatic and 63 FIP cats were analyzed, and 16 SNP were identified in intron 1 of fIFNG. Among these SNP, the fFING $+428 T$ allele was shown to be a FIP-resistant allele $(p=0.03)$, and the heterozygous genotypes $01 \mathrm{C} / T$ and $+408 \mathrm{C} / T$ were found to be FIP-susceptible factors $(p=0.004)$. Furthermore, an fIFNG +428 resistant allele also showed a clear correlation with the plasma level of IFN- $\gamma$ in FIP cats. For the identification of these three FIP-related SNP, genotyping methods were established using amplification refractory mutation system PCR (ARMS-PCR) and restriction fragment length polymorphisms (RFLP), and the different genotypes could easily be identified without sequencing. The identification of additional FIP-related SNP will allow the selection of resistant cats and decrease the morbidity of the cat population to FIP.
\end{abstract}

\section{Introduction}

Feline infectious peritonitis (FIP) is an immune-mediated disease caused by feline coronavirus (FCoV) infection. Despite the vast number of studies conducted since the recognition of FIP [1], neither effective vaccines nor therapeutic agents are available for the prevention or treatment of this often fatal disease. Therefore, it remains one of the most important feline infectious diseases.

Despite the ubiquitous existence of $\mathrm{FCoV}$ in cat populations around the world, the development of FIP was only observed in fewer than $5 \%$ of the FCoV-infected cats [2]. In addition, during the past few decades, several studies were conducted using various $\mathrm{FCoV}$ isolates, and regardless of the dose of virulent $\mathrm{FCoV}$, some cats survived from the experimental infection [2-11]. Genetic polymorphisms in the host were suggested to be important in the resistance to FIP [2]; however, no specific gene

\footnotetext{
* Correspondence: linglingchueh@ntu.edu.tw

Graduate Institute of Veterinary Medicine, School of Veterinary Medicine, National Taiwan University, Taipei 10617, Taiwan
}

with a clear correlation to resistance to this disease has ever been identified.

The protective immunity to FIP is thought to result mainly from cell-mediated immunity (CMI), and changes in the expression of several cytokines have been observed in cats with either experimentally induced or naturally occurring FIP [2]. The expression of one of the cytokines studied, interferon- $\gamma$ (IFN- $\gamma$ ), was consistently decreased in diseased animals, and this gene is thought to play a protective role in the pathogenesis of FIP, since it is a key cytokine in CMI [6,8,12-14].

In recent decades, single nucleotide polymorphisms (SNP) in the IFN- $\gamma$ gene (IFNG) have been found to be associated with various pathological conditions in humans [15] as well as in ruminants and fowl [16-23]. Nevertheless, this gene has not been investigated in cats. To identify a possible association between feline IFNG (fIFNG) SNP and the outcome of FCoV infection, some regions of the fIFNG gene were sequenced and analyzed. Three SNP with statistical relevance were found to be associated with the occurrence of FIP, 
and polymerase chain reaction (PCR) assays based on these differences were designed as a potential screening test for the selection of FIP-resistant populations.

\section{Materials and methods Specimens}

Whole blood and buccal swabs were collected from 82 FCoV-infected asymptomatic cats and 64 FIP cats from 2005 to 2012 at the National Taiwan University Animal Hospital for the association analysis. All asymptomatic healthy cats were three years old or younger and had positive reverse transcription-nested PCR test results for FCoV infection [24] in any of the following samples upon first arriving at the hospital: whole blood or nasal, oral, conjunctival, or rectal swabs. In addition, these cats showed no FIP-related symptoms when recruited into the study, and except for 12 cats, they stayed healthy for at least two years. All the FIP cases enrolled in this study were cats showing typical clinical signs of FIP and further confirmed by necropsy, histopathological examinations and FCoV detection [24] in disease-associated tissues, i.e. body effusions, kidney, liver, spleen, mesenteric lymph node, lung, and/or brain.

To elucidate the role of host genetic background in the development of FIP, two viral pathogens, i.e. feline immunodeficiency virus (FIV) and feline leukemia virus $(\mathrm{FeLV})$, that cause immunosuppression in cats were checked in FIP cats using nested PCR $[25,26]$, and the positive cats were omitted from the association analysis.

\section{Identification of SNP in the partial fIFNG sequences}

The genomic DNA from each cat was extracted using a genomic DNA mini kit (Geneaid Biotech, New Taipei City, Taiwan), and partial fIFNG sequences were amplified by PCR. Briefly, the genomic DNA was amplified with primers aligning to either the $5^{\prime}$ proximal regulatory region and intron 1 or the $5^{\prime}$ untranslated region and exon 2 of fIFNG (Table 1), and the PCR products were then sequenced from both ends using an auto sequencer ABI 3730XL (Applied Biosystems, San Mateo, USA). The sequences were aligned by Geneious 3.8.5 (Biomatters, Auckland, New Zealand), and the polymorphisms were identified.

Linkage disequilibrium (LD) test and association analysis An LD test and the creation of an LD plot were performed using $\mathrm{LD}_{2}$ SNPing v 2.0 (Department of Electronics Engineering, National Kaohsiung University of Applied Science, Kaohsiung, Taiwan) [27]. The associations between SNP and the outcome of FCoV infection were analyzed. A Fisher's exact test value of $P<0.05$ was considered to represent a significant association.

Table 1 Primers used for the identification of SNP, ARMS-PCR and RFLP

\begin{tabular}{|c|c|c|c|c|c|}
\hline Primer & Orientation $^{\mathrm{a}}$ & Position $^{\mathbf{b}}$ & Sequence $\left(5^{\prime}-3^{\prime}\right)^{c}$ & $T_{A}^{d}$ & Amplicon size \\
\hline \multicolumn{6}{|l|}{ Identification of SNP } \\
\hline \multirow[t]{2}{*}{$5^{\prime}-P_{R R}{ }^{e}$ intron 1} & $\mathrm{~F}$ & $-677 \sim-654$ & CAGGGCAATGCAAAGCTGTGGTAG & $65^{\circ} \mathrm{C}$ & $1306 \mathrm{bp}$ \\
\hline & $\mathrm{R}$ & $+629 \sim+607$ & GCGGCAGTAGAACTTTGAAACCA & & \\
\hline \multirow[t]{2}{*}{$5^{\prime}-U T R^{f}-$ exon 2} & $\mathrm{~F}$ & $-44 \sim-25$ & CGGAGCTACTGATTTCAACT & $63^{\circ} \mathrm{C}$ & $1434 \mathrm{bp}$ \\
\hline & $\mathrm{R}$ & $+1390 \sim+1371$ & GGAAAGAGGTAAGCTGGGTA & & \\
\hline \multicolumn{6}{|l|}{ Genotyping $^{g}$} \\
\hline \multirow[t]{4}{*}{+401} & $\mathrm{~F}$ (universal) & $+320 \sim+341$ & GGGGCATTCATCAGTCTTCCAG & $56^{\circ} \mathrm{C}$ & $200 \mathrm{bp}$ \\
\hline & R (universal) & $+519 \sim+500$ & AAGGTCAGGGTTAGCATGAA & & \\
\hline & $\mathrm{F}$ ( $T$ allele) & $+382 \sim+402$ & TAATITGTGGTGAGAATCTA & & $138 \mathrm{bp}$ \\
\hline & R (C allele) & $+418 \sim+400$ & CAACATCACAGTCTAATGG & & $99 \mathrm{bp}$ \\
\hline \multirow[t]{2}{*}{+408} & $\mathrm{~F}$ & $+320 \sim+341$ & GGGGCATTCATCAGTCTTCCAG & $56^{\circ} \mathrm{C}$ & $200 \mathrm{bp}$ \\
\hline & $\mathrm{R}$ & $+519 \sim+500$ & AAGGTCAGGGTTAGCATGAA & & \\
\hline \multirow[t]{4}{*}{+428} & $\mathrm{~F}$ (universal) & $+288 \sim+307$ & TACCCTCTGCTCAACTTGCT & $67^{\circ} \mathrm{C}$ & $232 \mathrm{bp}$ \\
\hline & R (universal) & $+519 \sim+500$ & AAGGTCAGGGTTAGCATGAA & & \\
\hline & $\mathrm{F}$ ( $T$ allele) & $+408 \sim+429$ & CTGTGATGTTGGGTAGTGTGTC & & 112 bp \\
\hline & R (C allele) & $+449 \sim+427$ & GGCTAGTCATTGTTTCAATAGGC & & 162 bp \\
\hline
\end{tabular}

${ }^{\mathrm{a}} F$ : forward; $R$ : reverse.

${ }^{\mathrm{b}}$ The nucleotide positions start from the first translation start point $(+1)$.

${ }^{\mathrm{C}}$ The italicizing indicates the target SNP.

${ }^{\mathrm{d}}$ Annealing temperature.

$\mathrm{e}^{\mathrm{i}} \mathrm{t}^{\prime}$-proximal regulatory region.

$f_{5}$ '-untranslated region.

${ }^{9} \mathrm{PCR}$ was done with a heating and cooling rate of 3 and $2{ }^{\circ} \mathrm{C}$, respectively. 


\section{Quantification of IFN- $\gamma$ levels in the plasma samples of FIP cats}

The plasma samples of FIP cats collected at the day of presentation were stored at $-20{ }^{\circ} \mathrm{C}$ before use. The concentration of IFN- $\gamma$ in the plasma samples was determined using an antigen capture ELISA ( $R$ \& D system, McKinley Place NE, USA) following the procedure advised by the manufacturer's instructions.

\section{Genotyping of SNP by tetra-primer amplification refrac- tory mutation system PCR (ARMS-PCR) and restriction fragment length polymorphisms (RFLP)}

For the genotyping of SNP using ARMS-PCR, the PCR reactions contained $1 \mu \mathrm{L}$ of template DNA, each primer at $500 \mathrm{nM}, 200 \mu \mathrm{M}$ dNTP, $1.5 \mathrm{mM} \mathrm{MgCl}_{2}$, and $0.4 \mathrm{U}$ Phusion DNA polymerase (Thermo Scientific, Waltham, USA) in a total volume of $20 \mu \mathrm{L}$ with $1 \times$ Phusion HF buffer. The primers and PCR conditions are listed in Table 1 . The PCR products were resolved in $2 \%$ agarose gels and photographed using an imaging system. The PCR for the genotyping of SNP with RFLP was carried out with the same protocol, and the PCR products were digested with HpyCH4III (New England Biolabs, Ipswich, USA) following the manufacturer's instructions. The digested DNA was resolved in $2 \%$ agarose gels and photographed using an imaging system.

\section{Results}

\section{Polymorphisms in fIFNG}

Due to a lack of information on polymorphisms in fIFNG, DNA from 40 cats, including 20 asymptomatic and 20 FIP cats, was sequenced throughout the proximal regulatory region, the $5^{\prime}$-UTR, exon 1 , intron 1 and a partial exon 2 region of fIFNG. In the 2067 bp analyzed, 3 repeat regions and 16 SNP were identified (Figure 1A). Among these 19 polymorphisms, only one was located in the proximal regulatory region, and the others were in intron 1 . No polymorphisms were identified in the $5^{\prime}$-UTR, exon 1 or exon 2. Intron 1 was more polymorphic than the upstream region of fIFNG. The allele frequencies of all the SNP surveyed were identified and are listed in Figure 1. The mean allele frequencies of the minor alleles ranged from $4.8 \%$ to $47.6 \%$.

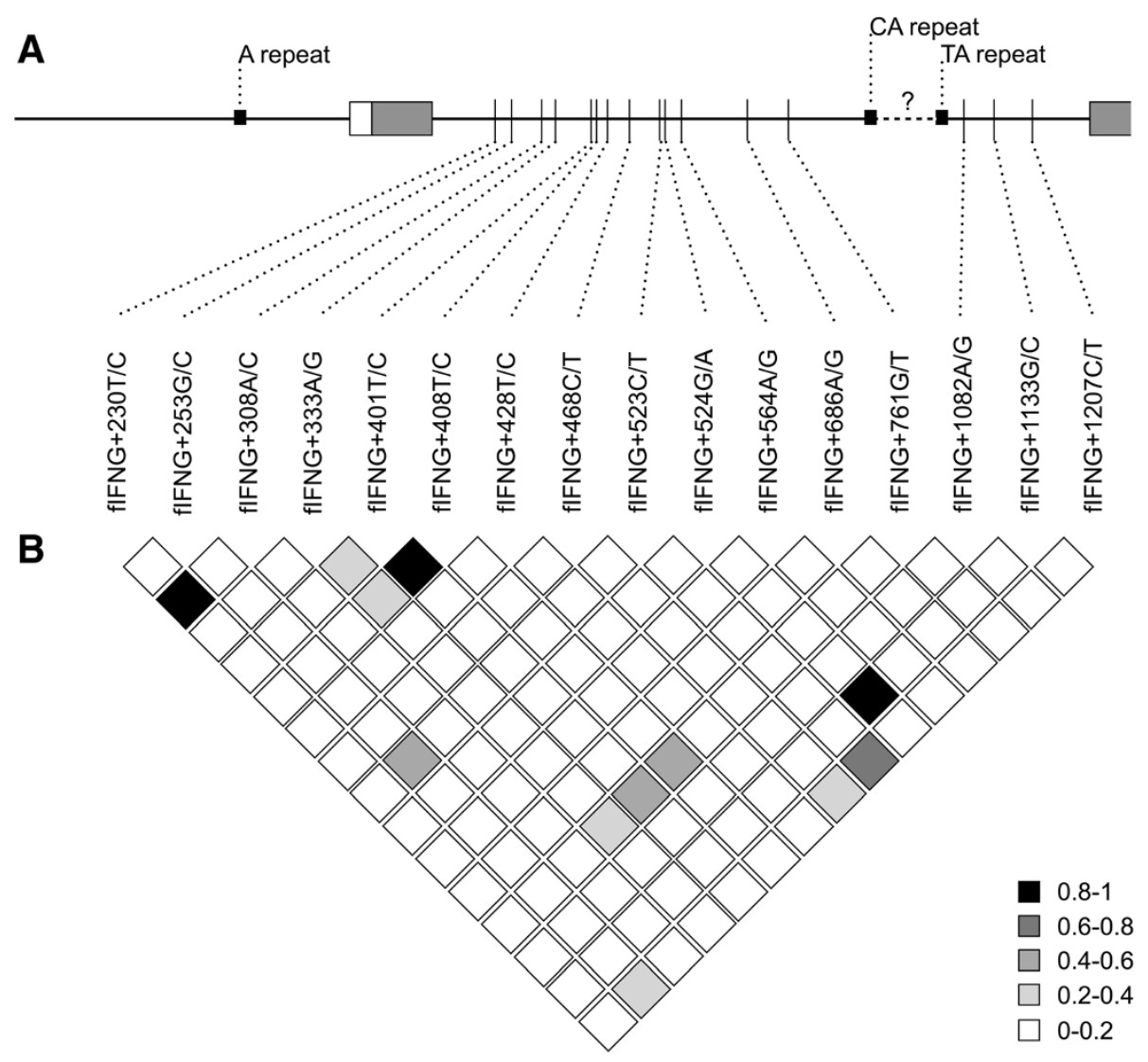

Figure 1 A schematic of the partial fIFNG sequences analyzed in this study. (A) A partial fIFNG sequence of 2067 bp was sequenced in this study, including the 5' proximal regulatory region, 5' UTR, exon 1, intron 1 and a partial exon 2 region. Black box: repeat region. White box: $5^{\prime}$ UTR. Gray boxes: exons 1 and 2. ?: a $~ 115$ bp region between 2 repeat regions of unknown sequence. (B) LD plot of the 16 SNP tested in this study. The $r^{2}$ values between different SNP are indicated by different colors. 
The SNP were then subjected to LD analysis. An LD plot of all the SNP for the whole population, including asymptomatic and FIP cats, was generated (Figure 1B). Three pairs of SNP were found to be significantly associated $\left(\mathrm{r}^{2}>0.8\right):$ fIFNG $+230 \mathrm{~T} / \mathrm{C}$ and fIFNG $+308 \mathrm{~A} / \mathrm{C}$, fIFNG $+401 \mathrm{~T} / \mathrm{C}$ and fIFNG $+408 \mathrm{~T} / \mathrm{C}$, and fIFNG $+524 \mathrm{G} /$ $A$ and fIFNG + 1133G/C. fIFNG +230 and fIFNG +308 and fIFNG +401 and fIFNG + 408 had a high degree of LD and were inherited together $100 \%$ of the time.

\section{Association study}

To elucidate the association between the identified SNP and the outcome of $\mathrm{FCoV}$ infection, the frequency of each genotype (Additional file 1) and allele (Additional file 2) was analyzed in 82 asymptomatic and 63 FIV and FeLV-free FIP cats. From all the SNP tested, only fIFNG $+428 \mathrm{C} / \mathrm{T}$ was found to be significantly associated with the outcome of the infection. At position +428 , there was a higher frequency of the $C T$ genotype in asymptomatic control cats (19.5\%) than in FIP cats (6.3\%), and the data showed a significant correlation with disease resistance $(p=0.03)$ (Table 2). Similarly, the analysis of allele frequency and disease outcome also revealed that the $T$ allele at position +428 was significantly associated with resistance to FIP $(p=0.03)$ (Table 2).

Although both types I and II FCoV can cause FIP, type II FCoV has been found to be more related to acute infection [28] and can cause horizontal transmission [29] whereas infection with type I viruses often results in persistent infection [30], therefore the host genotype involved in type I FCoV infection likely influences the resistance to a greater extent. To gain a better insight into the effect of host genetic variation in fIFNG and FIP, 29 type I FCoV-infected FIP cats were selected for further analysis (Additional files 3 and 4). After analyzing the target population, despite no allele of any SNP showing an association with the infection outcome (Table 3 ), the heterozygous genotype (CT genotype) at positions +401 and +408 were found to be significantly associated with susceptibility to FIP $(p=0.004)$ (Table 3 ).

Table 2 FIP-associated SNP in fIFNG identified in the whole cat population in this study

\begin{tabular}{cllll}
\hline SNP & $\begin{array}{l}\text { Control } \\
\text { number (\%) }\end{array}$ & $\begin{array}{l}\text { FIP } \\
\text { number (\%) }\end{array}$ & OR (95\% Cl) & $P$ \\
\hline fIFNG + $\mathbf{4 2 8}$ & & & & \\
CC & $66(80.5)$ & $60(93.8)$ & $3.6(1.2-11.5)$ & 0.03 \\
CT & $16(19.5)$ & $4(6.3)$ & Reference & \\
$T T$ & $0(0.0)$ & $0(0.0)$ & $\ldots{ }^{\circ}$ & \\
Allele C & $148(90.2)$ & $124(96.9)$ & $3.4(1.1-10.3)$ & 0.03 \\
Allele $T$ & $16(9.8)$ & $4(3.1)$ & Reference & \\
\hline
\end{tabular}

${ }^{a}$ no OR can be calculated.
Table 3 FIP-associated SNP in fIFNG identified in the type I FCoV-infected cats

\begin{tabular}{|c|c|c|c|c|}
\hline SNP & $\begin{array}{l}\text { Control } \\
\text { number (\%) }\end{array}$ & $\begin{array}{l}\text { FIP } \\
\text { number (\%) }\end{array}$ & OR $(95 \% \mathrm{Cl})$ & $P$ \\
\hline \multicolumn{5}{|l|}{ fIFNG + 401} \\
\hline$T T$ & $43(52.4)$ & $11(37.9)$ & $0.4(0.2-0.9)$ & 0.004 \\
\hline$C T$ & 26 (31.7) & $18(62.1)$ & Reference & \\
\hline$C C$ & $13(15.9)$ & $0(0.0)$ & $\mathrm{n} / \mathrm{a}^{\mathrm{a}}$ & \\
\hline Allele C & $112(68.3)$ & $40(69.0)$ & $\ldots^{b}$ & 1.00 \\
\hline Allele $T$ & $52(31.7)$ & $18(31.0)$ & $\ldots$ & \\
\hline \multicolumn{5}{|l|}{ fIFNG + 408} \\
\hline$T T$ & $43(52.4)$ & 11 (37.9) & $0.4(0.2-0.9)$ & 0.004 \\
\hline$C T$ & $26(31.7)$ & $18(62.1)$ & Reference & \\
\hline$C C$ & $13(15.9)$ & $0(0.0)$ & $\mathrm{n} / \mathrm{a}^{\mathrm{a}}$ & \\
\hline Allele C & $112(68.3)$ & 40 (69.0) & .. & 1.00 \\
\hline Allele $T$ & 52 (31.7) & $18(31.0)$ & .. & \\
\hline
\end{tabular}

anot available.

${ }^{\mathrm{b}}$ no OR can be calculated.

\section{Production of IFN- $\gamma$ in FIP cats carrying different genotypes}

To further validate the correlation between FIP-associated SNP and the production of IFN- $\gamma$, the concentration of IFN- $\gamma$ in the plasma samples from 15 FIP cats was measured. For most of the FIP cats $(12 / 15 ; 80 \%)$, the concentration was below the detection limit $(<3.125 \mathrm{pg} / \mathrm{mL})$ except for three cats. The concentrations of IFN- $\gamma$ for cat 14, 17, and 69 were 52, 138 and $>8000 \mathrm{pg} / \mathrm{mL}$, respectively (Figure 2, Additional file 5). These three animals were the only cats carrying the resistant allele ( $T$ allele) at position +428 whereas others were fIFNG $+428 C C$ genotype (Figure 2B, Additional file 5). For the fIFNG + $401 /+408$, however, no clear correlation between the IFN- $\gamma$ responses and genotypes was observed (Figure 2A, Additional file 5).

\section{Genotyping for disease-related SNP}

Through the association analysis and the quantification of plasma IFN- $\gamma$ level, fIFNG $+428 C / T$ was found to be associated with FIP and the plasma concentration of IFN- $\gamma$. In addition to this SNP, fIFNG +401C/T and fIFNG + $408 \mathrm{C} / \mathrm{T}$ were also shown to be associated with the type I FCoV-infected FIP population. To develop screening that can easily distinguish the resistant cats from the at-risk ones, ARMS-PCR specific for fIFNG $+428 C / T$ and fIFNG $+401 C / T$ was attempted. Using the tetra primer ARMS-PCR, the different alleles at position +401 could be successfully distinguished: universal control product: 200 bp; $T$ allele: 138 bp; $C$ allele: 99 bp (Figure 3A). Similarly, the $C$ and $T$ alleles could be determined at position +428: universal control product: 232 bp; $C$ allele: 162 bp; $T$ allele: 112 bp (Figure 3C). For fIFNG +408 , 

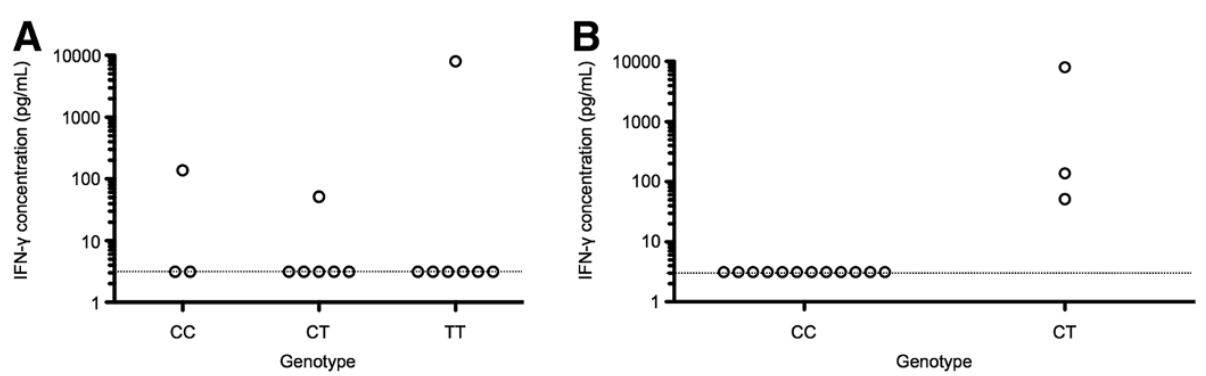

Figure 2 Plasma concentration of IFN- $\gamma$ in FIP cats carrying different genotypes at positions $+401 /+408$ (A) and +428 (B). The concentration of IFN- $\gamma$ was measured using antigen capture ELISA. A dotted line indicates the detection limit of the assay.

RFLP was used for genotyping, and the digested PCR products for the $T$ allele could be found at $151 \mathrm{bp}$ and $54 \mathrm{bp}$; the digested PCR products for the $C$ allele could be found at $113 \mathrm{bp}, 54 \mathrm{bp}$, and $43 \mathrm{bp}$ (Figure 3B).

\section{Discussion}

The occurrence of FIP is thought to be largely affected by viral virulence factors, and their roles in FIP have been intensely studied. Several viral genes, including spike [31-33], accessory gene $3 c$ [34-36] and 7b [37-39], and membrane [40], have been proposed to play important roles in the development of the disease in FCoV-infected cats. As a disease with immunopathogenesis entity, the knowledge of the host genetic factors that affect FIP is still very limited, and only two studies have reported such factors $[41,42]$, in contrast to the considerable quantity of information on the virulence factors.

Addie et al. who conducted the first study, attempted to reveal the genetic background of the cats and their associations with the occurrence of FIP (Table 4) [42]. Considering its important role in the defense against viral infection, feline leucocyte antigen (FLA)-DRB polymorphisms were analyzed in four different domestic shorthaired (DSH) or other purebred populations: FIP, FCoV carrier, transient infection and resistant. However, no association was found between any of the FLA-DRB polymorphisms and the occurrence of FIP, which might be due to the small sample size (FIP: 8 cats; asymptomatic: 17 cats) used. To gain better insight, a larger number of cats in each population was used (FIP: 63 cats; asymptomatic: 82 cats), and the association was clearly observed in the present study (Table 4).

Recently, several FIP-associated SNP were identified by a massive screen of Birman cats using a commercialized SNP gene chip, and the candidate genes were located from $69 \mathrm{~kb}$ to more than $1 \mathrm{Mb}$ away from the identified SNP (Table 4) [41]. In contrast to that report, the SNP were located within the candidate gene, fIFNG, in our study, which demonstrates a stronger linkage of the analyzed SNP to the candidate gene. In addition, the cat populations enrolled in this study, including approximately $50 \%$ DSH and another 50\% pure breed or mixed breed cats, were more variable, and the SNP associated with the disease may have been better represented on the entire cat population.

IFN- $\gamma$ is a crucial regulatory cytokine in CMI and is important for the control of intracellular pathogens. In $\mathrm{FCoV}$ infection, decreased IFN- $\gamma$ production in FIP cats was consistently observed in multiple studies [6,8,12-14]. In addition, in FCoV-infected non-FIP cats, the peripheral blood mononuclear cells showed a significant increase in the IFN- $\gamma$ response upon stimulation with the FCoV antigen when compared to the FIP cats [3]. The expression of
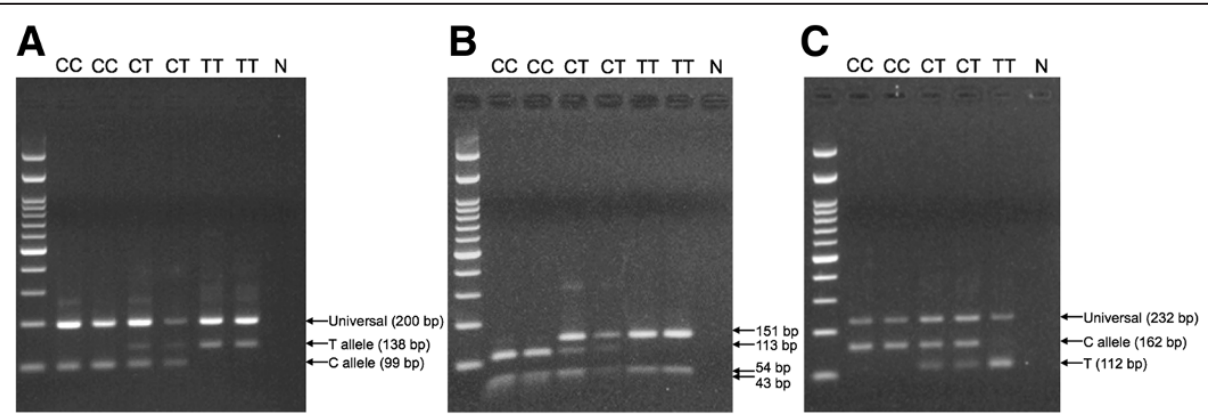

Figure 3 The ARMS-PCR and RFLP established in this study for the genotyping at positions +401 (A), +408 (B) and +428 (C). The primers and PCR conditions are listed in Table 1. The PCR products (A and C) and the RFLP products (B) were resolved in $2 \%$ agarose gel and photographed. 
Table 4 Studies conducted on host genetic polymorphisms and their associations with FIP

\begin{tabular}{|c|c|c|c|c|c|}
\hline Target & Method & Breed & Grouping (number of cats) & Polymorphism associated with FIP & Reference \\
\hline \multirow[t]{4}{*}{ FLA-DRB } & 1. Clonal sequence analysis & $\mathrm{DSH}^{\mathrm{b}}$ and Pure breed & 1. FIP (8) & Non & {$[42]$} \\
\hline & 2. $\operatorname{RSCA}^{\mathrm{a}}$ & & 2. Carrier (4) & & \\
\hline & & & 3. Transient (10) & & \\
\hline & & & 4. Resistant (3) & & \\
\hline \multirow[t]{5}{*}{ Identified SNP } & SNP gene chip & Birman cats & 1. FIP (34) & 1. A2.191286425 - ELMO1 & [41] \\
\hline & & & 2. Healthy (151) & 2. A1.196617776 - ERAP1, 2 & \\
\hline & & & & 3. A1.206840008 - ERAP1, 2 & \\
\hline & & & & 4. Un.59861682 - ERAP1, 2 & \\
\hline & & & & 5. E2.65509996-UI ${ }^{c}$ & \\
\hline \multirow[t]{3}{*}{ fIFNG } & PCR and sequencing & DSH and Pure breed & 1. FIP (63) & 1. fIFNG +401 & This study \\
\hline & & & 2. Healthy (82) & 2. $f I F N G+408$ & \\
\hline & & & & 3. $f I F N G+428$ & \\
\hline
\end{tabular}

${ }^{a}$ Reference strand mediated conformational analysis.

${ }^{\mathrm{b}}$ Domestic shorthaired.

'Unidentified.

IFN- $\gamma$ was thought to protect against $\mathrm{FCoV}$ infection. In several studies on human viral infections, i.e., human immunodeficiency virus [43], hepatitis B and hepatitis C $[44,45]$, a similar correlation between the magnitude of the IFN- $\gamma$ response and disease manifestation was identified. The polymorphisms in IFNG were associated with the diseases caused by these viruses [46-48].

The SNP associated with FIP are located in the intron 1 region. Therefore, it is unlikely that they mediate the outcome of the infection directly by altering the function of IFN- $\gamma$. In humans, IFNG polymorphisms have been found that correlate with the expression of IFN- $\gamma$. In the promoter region, SNP at positions -183 and -155 were found to influence the binding of activating transcription factor-1 and the nuclear factor-associated T-cell site $[49,50]$. In addition, the number of $C A$ microsatellite repeats was found to be tightly associated with the SNP at position +874 and to influence the production of IFN- $\gamma$ by altering the binding activity of nuclear factor kappalight-chain-enhancer of activated B cells [15]. In ewes, despite the polymorphisms in INFG at position -641, the microsatellite showed a significant effect on IFNG expression in the spleen, although the mechanism that mediates this effect remains unknown. In the present study, a clear correlation between the IFN- $\gamma$ responses and the genotype at position +428 was observed (Figure $2 \mathrm{~B}$ ). The resistant $T$ allele at position +428 may serve as a major factor to enhance the IFN- $\gamma$ production upon infections of intracellular pathogens. Despite lacking correlation with the IFN- $\gamma$ level, the SNP at positions +401 and +408 might still play a minor role in the alteration of the production of IFN- $\gamma$. Since the three FIP-related SNP identified in this study are located in a small cluster, it is possible that these polymorphisms alter the binding of one or more transcription factors and work together to influence the immune response to $\mathrm{FCoV}$ infection. However, the actual mechanism for the altered expression of IFN- $\gamma$ remains to be investigated.

In this study, three SNP in fIFNG were found to be associated with the outcome of FCoV infection. Using the ARMS-PCR and RFLP tests established, the three SNP could be distinguished in the ordinary diagnostic laboratory without sequencing, and cats bearing either the susceptible or resistant genotypes could be identified. Since the disease outcome is usually influenced by multiple host genes, other candidate genes, i.e., tumor necrosis factor- $\alpha$ [51,52], interleukin-12 [6] and CD209 [53], are currently being surveyed. A combination of all the FIPrelated SNP into a single genotyping microarray will allow the selection of resistant cats before breeding and eventually decrease the morbidity of the cat population to FIP.

\section{Additional files}

Additional file 1: Frequencies of the various genotypes and their associations with the outcome of FCoV infection. The CT genotype at position +428 was significantly associated with the resistance of FIP.

Additional file 2: Frequencies of various alleles and their associations with the outcome of FCoV infection. The T allele at position +428 was significantly associated with the resistance of FIP.

Additional file 3: Frequencies of various genotypes and their associations with the outcomes of type I FCoV infection. The heterologous genotypes of fIFNG +401 and fIFNG +408 were associated with the susceptibility to FIP in type I FCoV-infected cats.

Additional file 4: Frequencies of various alleles and their associations with the outcomes of type I FCoV infection. No allele of the analyzed SNP was associated with the occurrence of FIP in type I FCoV-infected cats. 
Additional file 5: Concentration of IFN- $\gamma$ in the plasma samples of FIP cats carrying different genotypes at positions $+401,+408$, and $\mathbf{4} \mathbf{4 2 8}$ on fIFNG. All the FIP cats carrying the CT genotype at position +428 were positive for the detection of plasma IFN- - .

\section{Competing interests}

The authors declare that they have no competing interests.

\section{Authors' contributions}

LEH performed the sample preparation, fIFNG amplification and sequencing measurement of the plasma concentration of IFN- $\gamma$, established genotyping methods and prepared the manuscript. LLC conceived the study, participated in the study design and coordination and contributed to the preparation of the manuscript. Both authors read and approved the final manuscript.

\section{Acknowledgements}

This work was supported by the grant NSC 102-2313-B-002- 027 from the National Science Council, Taiwan.

Received: 31 October 2013 Accepted: 28 April 2014

Published: 21 May 2014

\section{References}

1. Holzworth J: Some important disorders of cats. Cornell Vet 1963, 53:157-160

2. Pedersen NC: A review of feline infectious peritonitis virus infection: 1963-2008. J Feline Med Surg 2009, 11:225-258.

3. Satoh R, Furukawa T, Kotake M, Takano T, Motokawa K, Gemma T, Watanabe R, Arai S, Hohdatsu T: Screening and identification of T helper 1 and linear immunodominant antibody-binding epitopes in the spike 2 domain and the nucleocapsid protein of feline infectious peritonitis virus. Vaccine 2011, 29:1791-1800.

4. de Groot-Mijnes JD, van Dun JM, van der Most RG, de Groot RJ: Natural history of a recurrent feline coronavirus infection and the role of cellular immunity in survival and disease. J Virol 2005, 79:1036-1044.

5. Haijema BJ, Volders $H$, Rottier PJ: Live, attenuated coronavirus vaccines through the directed deletion of group-specific genes provide protection against feline infectious peritonitis. J Virol 2004, 78:3863-3871.

6. Kiss I, Poland AM, Pedersen NC: Disease outcome and cytokine responses in cats immunized with an avirulent feline infectious peritonitis virus (FIPV)-UCD1 and challenge-exposed with virulent FIPV-UCD8. J Feline Med Surg 2004, 6:89-97.

7. Hohdatsu T, Yamato H, Ohkawa T, Kaneko M, Motokawa K, Kusuhara H, Kaneshima T, Arai S, Koyama H: Vaccine efficacy of a cell lysate with recombinant baculovirus-expressed feline infectious peritonitis (FIP) virus nucleocapsid protein against progression of FIP. Vet Microbiol 2003, 97:31-44.

8. Dean GA, Olivry T, Stanton C, Pedersen NC: In vivo cytokine response to experimental feline infectious peritonitis virus infection. Vet Microbiol 2003, 97:1-12.

9. Wasmoen TL, Kadakia NP, Unfer RC, Fickbohm BL, Cook CP, Chu HJ, Acree WM: Protection of cats from infectious peritonitis by vaccination with a recombinant raccoon poxvirus expressing the nucleocapsid gene of feline infectious peritonitis virus. Adv Exp Med Biol 1995, 380:221-228.

10. Vennema H, de Groot RJ, Harbour DA, Horzinek MC, Spaan WJ: Primary structure of the membrane and nucleocapsid protein genes of feline infectious peritonitis virus and immunogenicity of recombinant vaccinia viruses in kittens. Virology 1991, 181:327-335.

11. Pedersen NC, Boyle JF, Floyd K: Infection studies in kittens, using feline infectious peritonitis virus propagated in cell culture. Am J Vet Res 1981, 42:363-367.

12. Gunn-Moore DA, Caney SM, Gruffydd-Jones TJ, Helps CR, Harbour DA: Antibody and cytokine responses in kittens during the development of feline infectious peritonitis (FIP). Vet Immunol Immunopathol 1998, 65:221-242.

13. Giordano A, Paltrinieri S: Interferon-gamma in the serum and effusions of cats with feline coronavirus infection. Vet J 2009, 180:396-398

14. Gelain ME, Meli M, Paltrinieri S: Whole blood cytokine profiles in cats infected by feline coronavirus and healthy non-FCoV infected specific pathogen-free cats. J Feline Med Surg 2006, 8:389-399.

15. Pravica V, Perrey C, Stevens A, Lee JH, Hutchinson IV: A single nucleotide polymorphism in the first intron of the human IFN-gamma gene: absolute correlation with a polymorphic CA microsatellite marker of high IFN-gamma production. Hum Immunol 2000, 61:863-866.

16. Maryam J, Babar ME, Nadeem A, Hussain T: Genetic variants in interferon gamma (IFN-gamma) gene are associated with resistance against ticks in Bos taurus and Bos indicus. Mol Biol Rep 2012, 39:4565-4570

17. Pant SD, Verschoor CP, Skelding AM, Schenkel FS, You Q, Biggar GA, Kelton DF, Karrow NA: Bovine IFNGR2, IL12RB1, IL12RB2, and IL23R polymorphisms and MAP infection status. Mamm Genome 2011, 22:583-588

18. Verschoor CP, Pant SD, Biggar GA, Schenkel FS, Sharma BS, Karrow NA: Identification of SNPs in interferon gamma, interleukin-22, and their receptors and associations with health and production-related traits in Canadian Holstein bulls. Anim Biotechnol 2011, 22:7-15.

19. Dervishi E, Uriarte J, Valderrabano J, Calvo JH: Structural and functional characterisation of the ovine interferon gamma (IFNG) gene: its role in nematode resistance in Rasa Aragonesa ewes. Vet Immunol Immunopathol 2011, 141:100-108.

20. Darlay RJ, McCarthy AJ, Illot NE, Smith JE, Shaw MA: Novel polymorphisms in ovine immune response genes and their association with abortion. Anim Genet 2011, 42:535-543.

21. Dukkipati VS, Blair HT, Garrick DJ, Lopez-Villalobos N, Whittington RJ, Reddacliff LA, Eppleston J, Windsor P, Murray A: Association of microsatellite polymorphisms with immune responses to a killed Mycobacterium avium subsp. paratuberculosis vaccine in Merino sheep. N Z Vet J 2010, 58:237-245.

22. Downing T, Lynn DJ, Connell S, Lloyd AT, Bhuiyan AK, Silva P, Naqvi AN, Sanfo R, Sow RS, Podisi B, O'Farrelly C, Hanotte O, Bradley DG: Contrasting evolution of diversity at two disease-associated chicken genes. Immunogenetics 2009, 61:303-314.

23. Kramer J, Malek M, Lamont SJ: Association of twelve candidate gene polymorphisms and response to challenge with Salmonella enteritidis in poultry. Anim Genet 2003, 34:339-348.

24. Herrewegh AA, de Groot RJ, Cepica A, Egberink HF, Horzinek MC, Rottier PJ: Detection of feline coronavirus RNA in feces, tissues, and body fluids of naturally infected cats by reverse transcriptase PCR. J Clin Microbiol 1995 33:684-689.

25. Nishimura $Y$, Goto $Y$, Pang $H_{\text {, Endo }}$, Mizuno T, Momoi $Y$, Watari T, Tsujimoto $H_{\text {, }}$ Hasegawa A: Genetic heterogeneity of env gene of feline immunodeficiency virus obtained from multiple districts in Japan. Virus Res 1998, 57:101-112.

26. Stiles J, Bienzle D, Render JA, Buyukmihci NC, Johnson EC: Use of nested polymerase chain reaction (PCR) for detection of retroviruses from formalin-fixed, paraffin-embedded uveal melanomas in cats. Vet Ophthalmol 1999, 2:113-116.

27. Chang HW, Chuang LY, Chang YJ, Cheng YH, Hung YC, Chen HC, Yang $C H$ : LD2SNPing: linkage disequilibrium plotter and RFLP enzyme mining for tag SNPs. BMC Genet 2009, 10:26

28. Lin CN, Su BL, Wang CH, Hsieh MW, Chueh TJ, Chueh LL: Genetic diversity and correlation with feline infectious peritonitis of feline coronavirus type I and II: A 5-year study in Taiwan. Vet Microbiol 2009, 136:233-239.

29. Wang YT, Su BL, Hsieh LE, Chueh LL: An outbreak of feline infectious peritonitis in a Taiwanese shelter: epidemiologic and molecular evidence for horizontal transmission of a novel type II feline coronavirus. Vet Res 2013, 44:57.

30. Addie DD, Schaap IA, Nicolson L, Jarrett O: Persistence and transmission of natural type I feline coronavirus infection. J Gen Virol 2003, 84:2735-2744.

31. Rottier PJ, Nakamura K, Schellen P, Volders H, Haijema BJ: Acquisition of macrophage tropism during the pathogenesis of feline infectious peritonitis is determined by mutations in the feline coronavirus spike protein. J Virol 2005, 79:14122-14130

32. Chang HW, Egberink HF, Halpin R, Spiro DJ, Rottier PJ: Spike protein fusion Peptide and feline coronavirus virulence. Emerg Infect Dis 2012, 18:1089-1095.

33. Licitra BN, Millet JK, Regan AD, Hamilton BS, Rinaldi VD, Duhamel GE, Whittaker GR: Mutation in spike protein cleavage site and pathogenesis of feline coronavirus. Emerg Infect Dis 2013, 19:1066-1073.

34. Vennema H, Poland A, Foley J, Pedersen NC: Feline infectious peritonitis viruses arise by mutation from endemic feline enteric coronaviruses. Virology 1998, 243:150-157.

35. Chang HW, de Groot RJ, Egberink HF, Rottier PJ: Feline infectious peritonitis: insights into feline coronavirus pathobiogenesis and epidemiology based on genetic analysis of the viral $3 c$ gene. J Gen Virol 2010, 91:415-420.

36. Hsieh LE, Huang WP, Tang DJ, Wang YT, Chen $C T$, Chueh LL: $3 C$ protein of feline coronavirus inhibits viral replication independently of the autophagy pathway. Res Vet Sci 2013, 95:1241-1247. 
37. Herrewegh AA, Vennema H, Horzinek MC, Rottier PJ, de Groot R: The molecular genetics of feline coronaviruses: comparative sequence analysis of the ORF7a/7b transcription unit of different biotypes. Virology 1995, 212:622-631.

38. Vennema H, Rossen JW, Wesseling J, Horzinek MC, Rottier PJ: Genomic organization and expression of the $3^{\prime}$ end of the canine and feline enteric coronaviruses. Virology 1992, 191:134-140.

39. Takano T, Tomiyama Y, Katoh Y, Nakamura M, Satoh R, Hohdatsu T: Mutation of neutralizing/antibody-dependent enhancing epitope on spike protein and $7 \mathrm{~b}$ gene of feline infectious peritonitis virus: influences of viral replication in monocytes/macrophages and virulence in cats. Virus Res 2011, 156:72-80.

40. Brown MA, Troyer JL, Pecon-Slattery J, Roelke ME, O'Brien SJ: Genetics and pathogenesis of feline infectious peritonitis virus. Emerg Infect Dis 2009, 15:1445-1452

41. Golovko L, Lyons LA, Liu H, Sorensen A, Wehnert S, Pedersen NC: Genetic susceptibility to feline infectious peritonitis in Birman cats. Virus Res 2013, 175:58-63.

42. Addie DD, Kennedy $\sqcup$, Ryvar R, Willoughby K, Gaskell RM, Ollier WE, Nart P, Radford AD: Feline leucocyte antigen class II polymorphism and susceptibility to feline infectious peritonitis. J Feline Med Surg 2004, 6:59-62.

43. Bailer RT, Holloway A, Sun J, Margolick JB, Martin M, Kostman J, Montaner L: IL-13 and IFN-gamma secretion by activated T cells in HIV-1 infection associated with viral suppression and a lack of disease progression. J Immunol 1999, 162:7534-7542.

44. Guidotti LG, Ando K, Hobbs MV, Ishikawa T, Runkel L, Schreiber RD, Chisari FV: Cytotoxic T lymphocytes inhibit hepatitis B virus gene expression by a noncytolytic mechanism in transgenic mice. Proc Natl Acad Sci U S A 1994, 91:3764-3768.

45. Heim MH: Innate immunity and HCV. J Hepatol 2013, 58:564-574

46. Qi S, Cao B, Jiang M, Xu C, Dai Y, Li K, Wang K, Ke Y, Ning T: Association of the -183 polymorphism in the IFN-gamma gene promoter with hepatitis B virus infection in the Chinese population. J Clin Lab Anal 2005, 19:276-281.

47. Kang MW, Pyo CW, Wie SH, Choi HB, Kim SY, Kim YK, Lee JS, Kim TG Associations of IFN-gamma polymorphism with HIV-1 infection in the Korean population. AIDS Res Hum Retroviruses 2006, 22:297-299.

48. Dai CY, Chuang WL, Hsieh MY, Lee LP, Hou NJ, Chen SC, Lin ZY, Hsieh MY, Wang LY, Tsai JF, Chang WY, Yu ML: Polymorphism of interferon-gamma gene at position +874 and clinical characteristics of chronic hepatitis $C$. Trans/ Res 2006, 148:128-133.

49. Chevillard C, Henri S, Stefani F, Parzy D, Dessein A: Two new polymorphisms in the human interferon gamma (IFN-gamma) promoter. Eur J Immunogenet 2002, 29:53-56.

50. Barbulescu K, Meyer zum Buschenfelde KH, Neurath MF: Constitutive and inducible protein/DNA interactions of the interferon-gamma promoter in vivo in [corrected] CD45RA and CD45R0 T helper subsets. Eur J Immunol 1997, 27:1098-1107.

51. Takano T, Hohdatsu T, Toda A, Tanabe M, Koyama H: TNF-alpha, produced by feline infectious peritonitis virus (FIPV)-infected macrophages, upregulates expression of type II FIPV receptor feline aminopeptidase N in feline macrophages. Virology 2007, 364:64-72.

52. Takano T, Hohdatsu T, Hashida Y, Kaneko Y, Tanabe M, Koyama H: A "possible" involvement of TNF-alpha in apoptosis induction in peripheral blood lymphocytes of cats with feline infectious peritonitis. Vet Microbiol 2007, 119:121-131.

53. Regan $A D$, Ousterout $D G$, Whittaker GR: Feline lectin activity is critical for the cellular entry of feline infectious peritonitis virus. J Virol 2010, 84:7917-7921.

doi:10.1186/1297-9716-45-57

Cite this article as: Hsieh and Chueh: Identification and genotyping of feline infectious peritonitis-associated single nucleotide polymorphisms in the feline interferon- $\gamma$ gene. Veterinary Research 2014 45:57.

\section{Submit your next manuscript to BioMed Central and take full advantage of:}

- Convenient online submission

- Thorough peer review

- No space constraints or color figure charges

- Immediate publication on acceptance

- Inclusion in PubMed, CAS, Scopus and Google Scholar

- Research which is freely available for redistribution

Submit your manuscript at www.biomedcentral.com/submit
Ciomed Central 